\title{
Effect of formative assessment of students on their academic performance in Department of Kriya Sharir
}

\author{
Pradnya D. Dandekar \\ Professor \& Head, Dept. of Kriya Sharir, MGACH \& C, Salod (H), Wardha, Maharashtra, India
}

*Corresponding Author: Pradnya D. Dandekar

Email: drpddandekar@rediffmail.com

\begin{abstract}
Assessment is an integral part of the teaching learning process. It helps us to know the success of specific teaching \& students' progress. Formative assessment is the informal way of knowing students progress. To evaluate the effect of Formative Assessment of the students on their Academic performance this project was undertaken. The randomly selected group of 40 students was taught the topic Rasa \& Rakta Dhatu at same time by using different types of teaching methods as didactic \& demonstration. Then they randomly divided into two groups. Group A $(\mathrm{N}=20)$ was Control Group. No any intervention given to the students. Group B $(\mathrm{N}=20)$ was Experimental Group. This group was given the interventions by conducting quiz and group discussion on the topic of Rasa \& Rakta Dhatu. Pretest and posttest based on MCQs to test recall memory \& SAQs test to check analyzing power were developed on the topic of Rasa \& Rakta Dhatu for both groups. The tests were then collected, scored and compiled. The students of Group B showed statistically significant improvement in recall memory which was tested by MCQs test $(\mathrm{p}=0.0001)$ \& to test descriptive \& analyzing power SAQs test was framed. Analysis showed enhancement in marks in SAQs but the result was not statistically significant. It was concluded that students assessed by formative assessment significantly score high than students who were not assessed. Formative assessment shows good effect on academic performance of the students \& helps in enhancement of learning.
\end{abstract}

Keywords: Formative assessment, Quiz, Group discussion, MCQs, SAQs, Academic performance.

\section{Introduction}

Learning is a process resulting in some change or modification in the learner's thinking, feeling and doing. The change may be temporary or permanent. In learning process assessment is very important. It is vital part of the education process. It helps us to know the success of specific teaching \& students' progress. It measures if and how students are learning and if the teaching methods are effectively relaying the intended messages. ${ }^{1}$ Black \& Wiliam in 1998 define assessment broadly to include all activities that teachers and students undertake to get information that can be used diagnostically to alter teaching and learning. Under this definition, assessment encompasses teacher observation, classroom discussion, and analysis of student work, including homework and tests. ${ }^{2}$

Assessment can be done as diagnostic, formative \& summative assessment. The diagnostic assessment can be done to identify areas of student need, or gaps in understanding, relative to key concept areas so that intervention activities can be efficiently and effectively targeted to students' levels of understanding and areas of need. ${ }^{3}$ During learning process, the continuous assessment is more likely to be formative, process-oriented, informal, internal, learner-involved, and/or self-referenced in nature. It can take the form of daily work (e.g. essays, quizzes, presentation and participation in class), projects/term papers and practical work (e.g. laboratory work, fieldwork, clinical procedures, drawing practice). Assessment become formative when the information is used to adapt teaching and learning to meet student needs. When teachers know how students are progressing and where they are having trouble, they can use this information to make necessary instructional adjustments, such as re-teaching, trying alternative instructional approaches, or offering more opportunities for practice. These activities can lead to improved student success. ${ }^{4}$

The goal of formative assessment is to monitor student learning to provide ongoing feedback that can be used by instructors to improve their teaching and by students to improve their learning. It does not contribute to the final mark given for the module; instead it contributes to learning through providing feedback. It indicates what is good about a piece of work and why this is good; it also indicates what is not so good and how the work could be improved. Effective formative feedback will affect what the student and the teacher does next.

In assessment we measure the students for their performance and correct them in case of any deviation. Formative assessment is the task which is used to help the learner and the teacher to know the progress of the students' academic performance in an informal way. ${ }^{5}$ The results of formative assessment are never used for final pass or fail decision. ${ }^{6}$ If this is done then the learners may try to hide their weaknesses and the main aim of formative assessment will be lost.

The Summative assessment is generally carried out at the end of course. ${ }^{5}$ It takes place after the learning has been completed and provides information and feedback that sums up the teaching and learning process. ${ }^{6}$ It demonstrates the extent of a learner's success in meeting the assessment criteria used to gauge the intended learning outcomes of a module or programme. Summative assessment is used to quantify achievement, to reward achievement. ${ }^{7}$

The marks of summative type of assessment are included in the pass or fail decision. So, this assessment does not give the direct feedback \& chance to correct for 
any deviation. Summative assessment is more productoriented and assesses the final product, whereas formative assessment focuses on the process toward completing the product. Once the project is completed, no further revisions can be made. If, however, students are allowed to make revisions, the assessment becomes formative, where students can take advantage of the opportunity to improve. The basic purpose of formative assessment is to help the learner know about his progress. It facilitates the improvement of teaching learning system also.

Keeping this view this study was designed to find out the impact of formative assessment on academic performance in Department of Kriya Sharir.

\section{Aim \& Objectives of the Study}

The Aim of proposed study is to evaluate the benefits of Formative Assessment of the students.

\section{Objectives of the Study}

1. Short Term -To evaluate the effect of Formative Assessment of the students on their Academic performance.

2. Long Term - To make the students as competent Physician in field of Ayurveda.

\section{Materials and Methods}

\section{Selection of subjects}

A group of 40 students out of 50 students studying in I B.A.M.S. class was selected randomly for the study. The students volunteered themselves after an orientation session in classroom. The institutional Ethics committee (Datta Meghe Institute of Health Sciences University) approved the protocol for this study. The details of the study explained to the subjects, their signed informed consent was taken.

\section{Study design}

The study included 40 students. The selected sample was divided into two equal groups, of which, one was experimental group and other was control group. The topic Rasa \& Rakta Dhatu was taught to both groups at same time by using different types of teaching methods as didactic \& demonstration. The two interventions of formative assessment in the form of Quiz \& group discussion were given to that of experimental group.

Group A $(\mathrm{N}=20)$ - Control Group: No any intervention given to the students.
Group B ( $\mathrm{N}=20)$ - Experimental Group: This group was given the interventions by conducting quiz and group discussion on the topic of Rasa \& Rakta Dhatu.

\section{Methodology}

Nature of the study was Interventional. The study used a pretest \& posttest for both groups. The study design included the participants randomly assign into control group and experimental group. A major strength of this design was to ensure that the students' varying levels of pretreatment knowledge was evenly distributed between the two treatment groups, thus eliminating the possibility of placing more participants into one group who already possessed a higher (or lower) level of knowledge of the intended content.

Pretest and posttest based on MCQs to test recall memory \& SAQs test to check analyzing power were developed on the topic of Rasa \& Rakta Dhatu for both groups. Identical pretests and posttests were used to test the achievement of students of both groups. Duration of MCQs (test 1) was 30 minutes \& the duration of SAQs (test 2) was 90 minutes. The tests were then collected, scored and compiled. To avoid partiality, the second topic on Kapha \& Pitta Dosha was selected to teach. For this topic the interventional \& control groups were interchanged. In this intervention Group A was experimental group \& Group B was control group. The same procedure was repeated. The topic Kapha \& Pitta Dosha was taught to both groups at same time by using different types of teaching methods as didactic \& demonstration. The two interventions of formative assessment in the form of Quiz \& group discussion were given to that of experimental group.

Pretest and posttest based on MCQs to test recall memory \& SAQs test to check analyzing power were developed on the topic of Kapha \& Pitta Dosha for both groups. Identical pretests and posttests were used to test the achievement of students of both groups. Duration of MCQs (test 1) was 30 minutes \& the duration of SAQs (test 2) was 90 minutes. The tests were then collected, scored and compiled.

Lastly feedback was taken to understand students' perception on formative assessment.

\section{Observations}

For topic Rasa Rakta Dhatu

Group A - Control Group

Group B - Experimental Group

Table 1: Shows numbers of males \& females participating in each study group

\begin{tabular}{|l|c|c|c|}
\hline Sex & Male & Female & Total \\
\hline Group A & $05(25 \%)$ & $15(75 \%)$ & $20(100 \%)$ \\
\hline Group B & $03(15 \%)$ & $17(85 \%)$ & $20(100 \%)$ \\
\hline Total & $08(20 \%)$ & $32(80 \%)$ & $40(100 \%)$ \\
\hline
\end{tabular}

Table 1 shows the predominance of female participation in Group $\mathrm{A}(75 \%)$ as well as in $\operatorname{Group} \mathrm{B}(80 \%)$. 
Table 2: Comparison of marks in control group at pre and post test $(\mathrm{N}=20)$

\begin{tabular}{|c|c|c|c|c|}
\hline & Group & Mean & Std. Deviation & Std. Error Mean \\
\hline \multirow{2}{*}{ Test 1} & Pre Test & 8.85 & 2.70 & 0.60 \\
\cline { 2 - 5 } & Post Test & 16.55 & 3.22 & 0.72 \\
\hline \multirow{2}{*}{ Test 2} & Pre Test & 2.100 & 1.131 & 0.253 \\
\cline { 2 - 5 } & Post Test & 11.875 & 3.609 & 0.807 \\
\hline
\end{tabular}

Table 3: Paired sample test in control group

\begin{tabular}{|l|c|c|c|c|c|c|c|}
\hline \multicolumn{2}{|c|}{ Mean } & \multirow{2}{*}{$\begin{array}{c}\text { Std. Error } \\
\text { Mean }\end{array}$} & \multicolumn{2}{|c|}{$\begin{array}{c}\text { 95\% Confidence Interval of } \\
\text { the Difference }\end{array}$} & \multirow{2}{*}{ t } & \multirow{2}{*}{ df } & p-value \\
\cline { 3 - 5 } & & & Lower & Upper & & & \\
\hline Test 1 & -7.70 & 0.744 & -9.26 & -6.14 & 10.35 & 19 & $0.0001 \mathrm{~S}, \mathrm{p}>0.05$ \\
\hline Test 2 & -9.775 & 0.720 & -11.283 & -8.267 & 13.57 & 19 & $0.0001 \mathrm{~S}, \mathrm{p}>0.05$ \\
\hline
\end{tabular}

Table 2 \& 3 compare the pre \& post test marks of MCQ (Test 1) \& SAQ (Test 2) based on Rasa-Rakta dhatu in control group. It shows significant increase in post test showing p value highly significant.

Table 4: Comparison of marks in experimental group $(\mathrm{N}=20)$ at pre and post test

\begin{tabular}{|c|c|c|c|c|}
\hline \multirow{2}{*}{ Test 1} & Group & Mean & Std. Deviation & Std. Error Mean \\
\hline \multirow{2}{*}{ Test 2} & Pre Test & 8.65 & 2.50 & 0.56 \\
\cline { 2 - 5 } & Post Test & 23.95 & 2.39 & 0.54 \\
\cline { 2 - 5 } & Pre Test & 2.600 & 1.107 & 0.248 \\
\hline
\end{tabular}

Table 5: Paired sample test in experimental group

\begin{tabular}{|c|c|c|c|c|c|c|c|}
\hline \multicolumn{5}{|c|}{ Paired Differences } & \multirow{3}{*}{$\mathbf{t}$} & \multirow{3}{*}{ df } & \multirow{3}{*}{ p-value } \\
\hline & \multirow[t]{2}{*}{ Mean } & \multirow{2}{*}{$\begin{array}{l}\text { Std. Error } \\
\text { Mean }\end{array}$} & \multicolumn{2}{|c|}{$\begin{array}{c}\text { 95\% Confidence Interval of } \\
\text { the Difference }\end{array}$} & & & \\
\hline & & & Lower & Upper & & & \\
\hline Test 1 & -15.30 & 0.70 & -16.77 & -13.83 & 21.86 & 19 & $0.0001 \mathrm{~S}, \mathrm{p}>0.05$ \\
\hline Test 2 & -10.75 & 0.457 & -11.706 & -9.794 & 23.54 & 19 & $0.0001 \mathrm{~S}, \mathrm{p}>0.05$ \\
\hline
\end{tabular}

Table 4 \& 5 compare the pre \& post test marks of MCQ (Test 1) \& SAQ (Test 2) based on Rasa-Rakta dhatu in experimental group. It shows significant increase in post test showing p value highly significant.

Table 6: Comparison of marks in both groups at pre and posttest

\begin{tabular}{|l|l|c|c|c|}
\hline & \multicolumn{1}{|c|}{ Group } & Mean & Std. Deviation & Std. Error Mean \\
\hline \multirow{2}{*}{ Test $1-$ Pre Test } & Experimental & 8.65 & 2.50 & 0.56 \\
\cline { 2 - 5 } & Control & 8.85 & 2.70 & 0.60 \\
\hline \multirow{2}{*}{ Test 1 - Post Test } & Experimental & 23.95 & 2.39 & 0.54 \\
\cline { 2 - 5 } & Control & 16.55 & 3.22 & 0.72 \\
\hline \multirow{2}{*}{ Test 2 -Pre Test } & Experimental & 2.600 & 1.107 & 0.248 \\
\cline { 2 - 5 } & Control & 2.100 & 1.131 & 0.253 \\
\hline \multirow{2}{*}{ Test 2 -Post Test } & Experimental & 13.350 & 1.886 & 0.422 \\
\cline { 2 - 5 } & Control & 11.875 & 3.609 & 0.807 \\
\hline
\end{tabular}

Table 7: Paired sample test in both group

\begin{tabular}{|l|c|c|c|c|}
\hline & \multicolumn{3}{|c|}{ t-test for Equality of Means } \\
\hline & t & df & p-value & Std. Error Mean \\
\hline Test 1-Pre Test & -0.20 & 38 & $\mathrm{P}=0.8092 \mathrm{NS}, \mathrm{p}>0.05$ & 0.823 \\
\hline Test 1-Post Test & 8.25 & 38 & $\mathrm{P}=0.0001 * \mathrm{~S}, \mathrm{p}>0.05$ & 0.897 \\
\hline Test 2-Pre Test & 1.75 & 38 & $\mathrm{P}=0.0961 \mathrm{NS}, \mathrm{p}>0.05$ & 0.286 \\
\hline Test 2-Post Test & 1.53 & 38 & $\mathrm{P}=0.1407 \mathrm{NS}, \mathrm{p}>0.05$ & 0.959 \\
\hline
\end{tabular}

Table 6 \& 7 compare the pre \& post test marks of MCQ (Test 1) \& SAQ (Test 2) based on Rasa-Rakta dhatu in both groups $\&$ it shows that in pre test comparison both groups are at equal level. In post test comparison the experimental group shows highly significant improvement in Test $1(\mathrm{p}=0.0001)$. In Test 2 the improvement in the marks observed in experimental group, but the improvement is not statistically significant $(\mathrm{p}=0.1407)$. 
For topic Kapha - Pitta Dosha

Group A - Experimental Group

Group B -Control Group

Table 8: Comparison of marks in control group at pre and post test $(\mathrm{N}=20)$

\begin{tabular}{|l|c|c|c|c|}
\hline & Group & Mean & Std. Deviation & Std. Error Mean \\
\hline \multirow{2}{*}{ Test 1} & Pre Test & 9.65 & 3.17 & 0.71 \\
\cline { 2 - 5 } & Post Test & 10.90 & 2.55 & 0.57 \\
\hline \multirow{2}{*}{ Test 2} & Pre Test & 8.150 & 1.857 & 0.415 \\
\cline { 2 - 5 } & Post Test & 17.400 & 2.588 & 0.579 \\
\hline
\end{tabular}

Table 9: Paired sample test in control group

\begin{tabular}{|c|c|c|c|c|c|c|c|}
\hline \multicolumn{5}{|c|}{ Paired Differences } & \multirow{3}{*}{$\mathbf{t}$} & \multirow{3}{*}{ df } & \multirow{3}{*}{ p-value } \\
\hline & \multirow[t]{2}{*}{ Mean } & \multirow[t]{2}{*}{ Std. Error Mean } & \multicolumn{2}{|c|}{$\begin{array}{c}\text { 95\% Confidence Interval of the } \\
\text { Difference }\end{array}$} & & & \\
\hline & & & Lower & Upper & & & \\
\hline Test 1 & -5.75 & 1.011 & -7.80 & -3.70 & 5.688 & 19 & $0.0001 \mathrm{~S}, \mathrm{p}>0.05$ \\
\hline Test 2 & -9.250 & 0.535 & -10.37 & -8.13 & 17.291 & 19 & $0.0001 \mathrm{~S}, \mathrm{p}>0.05$ \\
\hline
\end{tabular}

Table 8 \& 9 compare the pre \& post test marks of MCQ (Test 1) \& SAQ (Test 2) based on Kapha \& Pitta Dosha in control group. It shows significant increase in post test showing $\mathrm{p}$ value highly significant.

Table 10: Comparison of marks in experimental group $(\mathrm{N}=20)$ at pre and post test

\begin{tabular}{|l|c|c|c|c|}
\hline & Group & Mean & Std. Deviation & Std. Error Mean \\
\hline \multirow{2}{*}{ Test 1} & Pre Test & 9.65 & 3.17 & 0.71 \\
\cline { 2 - 5 } & Post Test & 21.10 & 4.52 & 1.01 \\
\hline \multirow{2}{*}{ Test 2} & Pre Test & 8.325 & 2.467 & 0.552 \\
\cline { 2 - 5 } & Post Test & 18.525 & 2.989 & 0.668 \\
\hline
\end{tabular}

Table 11: Paired sample test in experimental group

\begin{tabular}{|l|c|c|c|c|c|c|c|}
\hline \multicolumn{2}{|c|}{ Mean } & \multirow{2}{*}{$\begin{array}{c}\text { Std. Error } \\
\text { Mean }\end{array}$} & $\begin{array}{c}\text { 95\% Confidence Interval } \\
\text { of the Difference }\end{array}$ & \multirow{2}{*}{ t } & \multirow{2}{*}{ df } & \multirow{2}{*}{ p-value } \\
\cline { 3 - 5 } & & & Lower & Upper & & & \\
\hline Test 1 & -11.45 & 0.881 & -13.29 & -9.61 & 12.99 & 19 & $0.0001 \mathrm{~S}, \mathrm{p}>0.05$ \\
\hline Test 2 & -10.20 & 0.691 & -11.647 & -8.753 & 14.75 & 19 & $0.0001 \mathrm{~S}, \mathrm{p}>0.05$ \\
\hline
\end{tabular}

Table 10 \& 11 compare the pre \& post test marks of MCQ (Test 1) \& SAQ (Test 2) based on Kapha \& Pitta Dosha in experimental group. It shows significant increase in post test showing $\mathrm{p}$ value highly significant.

Table 12: Comparison of marks in both groups at pre and posttest

\begin{tabular}{|l|c|c|c|c|}
\hline & Group & Mean & Std. Deviation & Std. Error Mean \\
\hline \multirow{2}{*}{ Test 1 - Pre Test } & Experimental & 9.65 & 3.17 & 0.71 \\
\cline { 2 - 5 } & Control & 10.90 & 2.55 & 0.57 \\
\hline \multirow{2}{*}{ Test 1 - Post Test } & Experimental & 21.10 & 4.52 & 1.01 \\
\cline { 2 - 5 } & Control & 16.65 & 3.73 & 0.83 \\
\hline \multirow{2}{*}{ Test 2 -Pre Test } & Experimental & 8.325 & 2.467 & 0.552 \\
\cline { 2 - 5 } & Control & 8.150 & 1.857 & 0.415 \\
\hline Test 2 -Post Test & Experimental & 18.525 & 2.989 & 0.668 \\
\cline { 2 - 5 } & Control & 17.400 & 2.588 & 0.579 \\
\hline
\end{tabular}

Table 13: Paired sample test in both group

\begin{tabular}{|l|c|c|c|c|}
\hline & \multicolumn{4}{|c|}{ t-test for Equality of Means } \\
\hline & $\mathbf{t}$ & $\mathbf{d f}$ & p-value & Std. Error Mean \\
\hline Test 1-Pre Test & 1.367 & 38 & $\mathrm{P}=0.1876 \mathrm{NS}, \mathrm{p}>0.05$ & 0.914 \\
\hline Test 1-Post Test & 3.253 & 38 & $\mathrm{P}=0.0042 * \mathrm{~S}, \mathrm{p}>0.05$ & 1.368 \\
\hline Test 2-Pre Test & 0.2534 & 38 & $\mathrm{P}=0.8013 \mathrm{NS}, \mathrm{p}>0.05$ & 0.691 \\
\hline Test 2-Post Test & 1.249 & 38 & $\mathrm{P}=0.2269 \mathrm{NS}, \mathrm{p}>0.05$ & 0.901 \\
\hline
\end{tabular}


Table $12 \& 13$ compare the pre \& post test marks of MCQ (Test 1) \& SAQ (Test 2) based on Kapha \& Pitta Dosha in both groups \& it shows that in pre test comparison both groups are at equal level. In post test comparison the experimental group shows significant improvement in Test $1(\mathrm{p}=0.0042)$. In Test 2 the improvement in the marks observed in experimental group, but the improvement is not statistically significant $(\mathrm{p}=0.2269)$.

\section{Feedback Analysis}

Teaching program evaluation in medical education presents with a different set of challenges. The utility of such program is commonly gauged by some measures of outcome such as participants' general reactions. ${ }^{9}$ The outcome of teaching program has several dimensions. At the simplest level, it can be measured by students' perception. Donald Kirkpatrick's four level model is used for evaluation of this training program. Level one: Reaction, Level two: learning, Level three: transfer, Level four: results. Students' perception assessed by feedback analysis on the basis of Likert's scale. Formative assessment is very good to check the performance of students' this feedback given by all $100 \%$ participants, out of which 50\% are strongly agree to this statement. $100 \%$ participants also agree that it creates interest in learning process. Out of theses $50 \%$ are strongly recommended this statement. $70 \%$ students agree to opinion that formative assessments promote critical thinking process, $15 \%$ strongly agree \& $15 \%$ remain neutral on this statement. $68 \%$ are agreeing to statement that it reduces anxiety of summative examination \& $32 \%$ are strongly agreed to this. Formative assessments should be conducted regularly \& it improves our performance this was strongly recommended by $64 \%$ participants \& $36 \%$ agree to this statement. Regular assessment tests increases burden or stress on students. For this $20 \%$ were strongly disagree, $40 \%$ were disagreeing, $24 \%$ were neutral \& $16 \%$ were agreeing. For other questions no were disagree.

Graph 1: Feedback analysis

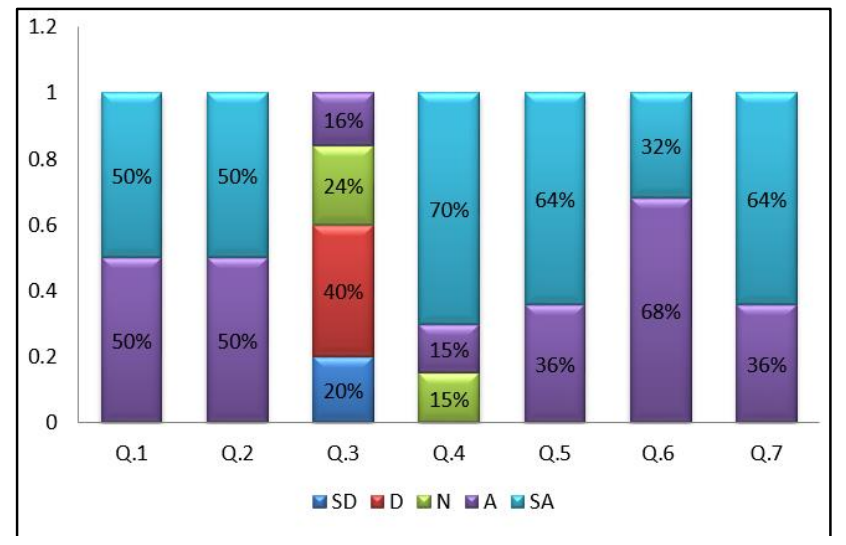

\section{Discussion}

In relation to the main aim of this research, the results are conclusive. The students that participated in formative assessment obtained better examination results in post conducted test than the ones that did not. In pre test both groups students were at equal levels. (Table 6) The same observations were observed after changing the group for intervention with selection of new topic (Table 12). Moreover, academic achievement in formative assessment was an important predictor of academic achievement. The results show that most of the students that got good marks in formative assessment also obtained good results in the Term examination. However, failing in formative assessment is not a predictor of examination failure. The students show statistically significant improvement in recall memory which was tested by MCQs test (Test 1) \& to test descriptive \& analyzing power tie SAQs test was framed. Students of experimental group show enhancement in marks but the result was not statistically significant.

Students' perception for formative assessment was positive feedback, that it definitely enhances their academic achievement.

\section{Conclusion}

It was concluded that students assessed by formative assessment significantly high score than students who were not assessed. Formative assessment shows good effects on academic performance of the students. It gives us timely student achievement information which is useful to monitor the student's progress in terms of what they understand \& where they are? It is also useful for teacher to assess the effectiveness of their instructions \& also warrants the teacher to modify teaching way.

\section{Limitations}

The results of formative assessment are never used for final pass or fail decision. So the students do not take them very seriously.

\section{Source of Funding}

None.

Conflict of Interest

None.

\section{References}

1. Hanna GS, Dettmer PA. Assessment for effective teaching: Using context-adaptive planning. Boston, MA: Pearson A\&B. 2; 2004 .

2. Mehmood T, Hussain T, Khalid M, Azam R. Impact of Formative Assessment on Academic Achievement of Secondary School Students, Int J Business Soc Sci. 2012;3(17).

3. http://myflorida.com/apps/vbs/vbs_www.ad.view_ad?advertise ment_key_num=107800.

4. Sawyer RJ, Graham S, Harris KR. Direct teaching, strategy instruction, and strategy instruction with explicit selfregulation: Effects on the composition skills and self-efficacy of students with learning disabilities. J Educ Psychol. 1992;84(3):340.

5. Singh T, Gupta P, Singh D. Principles of Medical Education' Jaypee Brothers Medical Publication, Third Edition 2009.

6. Ananthakrishnan N, Sethuraman, Kumar S. 'Medical Education- Principles \& Practice, Third Edition. 
7. Northern Illinois University, Faculty Development and Instructional Design Center facdev@niu.edu, http://facdev.niu.edu, 815.753.0595

8. Dunn K, Mulvenon SW. A critical review of research on formative assessment: the limited scientific evidence of the impact of formative assessment in education. Res Eval. 2009;14(7):10.

9. Bennett EB. Formative assessment: a critical review. Assess Educ: Princ, Policy Pract. 2011;18(1):5-25.

10. Amin Z, Hoon K. Basics in Medical Education, National University of Singapore; 2009.

11. Ruland JW. The Impact of using formative assessment attributes in daily instruction on student affect, dissertation submitted for doctoral degree; 2011.
12. Liebmann R. Sindberg M. The effects of incorporating formative assessment on testing, University of Wisconsin Oshkosh, WI 54901;2010.

13. Nicola DJ, Macfarlane D. Formative assessment and self regulated learning: A model and seven principles of good feedback practice. Stud Higher Educ. 2006;31(2):199-218.

How to cite: Dandekar PD. Effect of formative assessment of students on their academic performance in Department of Kriya Sharir. J Educ Technol Health Sci. 2020;7(1):33-8. 